\title{
Application for turnover order: a marble head of Alexander The Great as Helios, the sun god
} Solicitud de orden de devolución de una cabeza de mármol de Alejandro Magno como Helios, el dios sol

In 2017, the New York District Attorney's Office formed the first Antiquities Trafficking Unit in the world that combined prosecutors, law-enforcements agents, analysts, and paralegals in a single team. Since then, they have recovered more than $\$ 100$ million worth of antiquities and repatriated them to a dozen countries. In February of 2018, that unit received a judicial warrant to seize a circa-1stcentury CE marble head of Alexander the Great as Helios, the Sun God, from Safani Gallery Inc., under the authority of New York Criminal Procedure Law $§ 690.55$. This seizure was based on evidence that the object had been excavated from the Basilica Aemilia in the Roman Forum after September 1909; then stolen from a stateowned museum collection and thereafter illegally exported from the country of origin in contravention of Italy's cultural heritage law. In July 2018, the District Attorney's Office submitted an Application for Turnover in support of an order authorizing the transfer of the marble head to Italy, pursuant to New York Penal Law §450.10. This paper reproduces that application.

Keywords: "Head of Alexander", turnover order, illicit traffic antiquities.
En 2017, la Oficina del Fiscal de Nueva York estableció el Antiquities Trafficking Unit. Este fue el primer grupo contra el tráfico de patrimonio cultural en el mundo que reunió abogados, agentes, analistas y procuradores en el mismo equipo. Desde entonces, el "Unit" ha logrado recuperar antigüedades valoradas en más de cien millones de dólares y ha devuelto estos bienes culturales a docenas de países. En febrero de 2018, el Antiquities Trafficking Unit recibió una orden judicial para incautar una cabeza de mármol de Alejandro Magno representado como Helios, el dios sol, del siglo I d. C., confiscada de la galería de Safani Inc, de conformidad con el artículo 690.55 de la Ley de Procedimiento Penal de Nueva York. Esta incautación se basó en las sospechas de que el objeto había sido excavado en la Basílica de Aemilia en el Foro romano, después de septiembre de 1909, y luego robado de la colección de un museo de propiedad estatal y, en algún momento, exportado ilegalmente del país de origen en contravención de la legislación de patrimonio cultural de Italia. En julio de 2018, la Oficina del Fiscal de Nueva York presentó una solicitud de devolución del objeto que autorizaba la transferencia de la cabeza de mármol a Italia, de acuerdo con la ley penal de Nueva York §450.10. Este artículo reproduce dicha aplicación.

Palabras clave: "Cabeza de Alejandro", orden de devolución, tráfico ilícito de antigüedades. 
Supreme Court of the state of New York County of New York, part 52

In the matter of an application for a Warrant to search the premises of Safani Gallery, INC. Located at 7 e 75th street, suited 2d, New York, New York, 10021 ("The target premises")

\section{Application for turnover order}

Matthew Bogdanos, an attorney admitted to the practice of law in the State of New York, affirms the following under penalties of perjury:

1. I am a Senior Trial Counsel in the Office of New York County District Attorney Cyrus R. Vance Jr. ("Office") and am familiar with the facts of this case.

2. On January 3, 2019, the People submitted an application in support of an Order pursuant to Penal Law $\$ 450.10$ and Criminal Procedure Law $\$ 690.55$, authorizing the transfer of a marble Head of Alexander the Great as Helios, the Sun God (the "Head of Alexander"), from the custody of this court to its lawful owner: the Government of the Italian Republic. See Exhibit 1 (Photograph of Head of Alexander [Fig. 1]). ${ }^{1}$ The People herein provide a comprehensive factual account of the Head of Alexander's excavation, theft, subsequent ownership history, and seizure. Similarly, the People herein provide a single legal analysis as to why the marble Head of Alexander should be transferred from the custody of this court to the Italian government. There are two completely independent reasons-each sufficient in and of itself: the artifact was stolen from a stateowned archaeological complex and it was illegally exported from Italy after 1902.

\section{The Excavation of the Basilica Emilia at the Roman Forum}

3. The Head of Alexander was discovered during excavations at the site of the Roman Forum in Italy. An open-air, multipurpose, public gathering place and market, the Forum was the most important civic center in Ancient Rome from 800 B.C. to 600 A.D. Hosting everything from meetings, legal proceedings, and gladiatorial contests to religious and secular ceremonies, the Forum contained many of ancient Rome's most prized temples, monuments, and basilicas. The Head of Alexander comes from one such basilica within the Forum, the Basilica Emilia, located in the northern portion of the Forum on the Via Sacra-an ancient road between the Capitoline Hill and the Colosseum. Built in 179 B.C. and originally called the "Basilica Fulvia-Aemilia," the Basilica Emilia was a luxurious public hall once decorated with precious marbles and

1. The People first submitted an application on July 23, 2018. After that application, this Office continued the investigation, uncovering new and clarifying information. On January 3, 2019, the People filed an amended version of the application. On November 13, 2019, both the People and the Defense presented oral argument before the Honorable Thomas Farber. This application contains the People's January 3, 2019, amended application and the November 13, 2019, oral argument. columns. See Exhibit $2,^{2}$ for a map of the Forum complex. The Basilica Emilia is structure number 9.

4. In 1899, Italy began state-sponsored scientific excavations of the Roman Forum and nearby Palatine Hill. Professor Giacomo Boni directed the excavations until 1925, when his former assistant, Professor Alfonso Bartoli, took over. ${ }^{3}$ Professors Boni and Bartoli excavated the Basilica Emilia in two phases: from 1899-1900 and again starting in 1909.

5. During the initial phase from 1899-1900, larger and structural finds were kept where they had been found, but smaller finds-fragments, heads, vases-were moved to an enclosed, stone-walled room in the Basilica Emilia that was used for onsite storage and restoration until 1908. See Exhibit 3 (Photograph of Storage Room, post-1910)., 5 Then in 1908, a state-owned archaeological museum, the Museo Forense, was opened to house finds from the Forum and Palatine Hill. Renamed the Antiquarium Forense in 1935, the Museum was located inside the newly renovated convent of Santa Maria Nova within the Roman Forum complex. As soon as the Museum opened, smaller finds from the first phase were brought inside the Museum. All throughout the second phase, all new movable finds were temporarily housed in the Basilica Emilia storage room, but almost immediately moved to the Museo Forense for permanent storage. Only some architectural fragments and larger finds recovered during the excavations remained in the storage facility.

6. These practices are well-documented in both the written and photographic records of the Museum. One of the written records is Professor Bartoli's "Giornale dello Scavo in Corso" (Journal of Excavation in Progress) for the Basilica Emilia. In his journal, Professor Bartoli documented the discovery of some, but not all, excavated artifacts. Each entry included three columns: a sequential number in the left-hand margin $(1,2,3$, etc.); a description of the object or group of objects discovered; and the date of that discovery. See Exhibit 4 (Bartoli Journal). ${ }^{6}$ Professor Bartoli did not, however, assign unique inventory numbers to the listed artifacts, and his descriptions often refer to multiple objects in a single entry. It is, therefore, not always possible to determine with certainty which journal entry and date of discovery

2. This document, which accompanies the original application, for reasons of length of the paper does not form part of the present text (editors' note).

3. Professor Giacomo Boni (1859-1925) served as Excavation Director of the Roman Forum and Palatine Hill from 1899-1925. Professor Alfonso Bartoli (1874-1957) served in that capacity from 1925-1939.

4. According to Dr. Patrizia Fortini, Director and Coordinator of the Archaeological Site of the Roman Forum and Palatine Hill, both the state-owned storage facility and Forum have been secured by perimeter fencing and staff since the start of excavations. Unauthorized access to those areas has always been illegal.

5. This document, which accompanies the original application, for reasons of length of the paper does not form part of the present text (editors' note).

6. This document, which accompanies the original application, for reasons of length of the paper does not form part of the present text (editors' note) 
correspond to any specific find (including the Head of Alexander).

7. The photographic record is better, covering both the excavation site and the Museo Forense. Photographs taken at the excavation site detail the depth of soil removal and architectural fragments. See Exhibit 5 (Excavation Photographs 1-4). ${ }^{7,8}$ In 1910, American archaeologist Esther Boise van Deman also took photographs of the Basilica Emilia, detailing the excavations. See Exhibit 6 (Deman Excavation Photographs, 1910). ${ }^{9}$

8. Those photographs show architectural fragments and large finds on site, while the movable finds were brought to the Museo Forense to be photographed. Placed on a table against a black backdrop in the Museum's cloister, their images were captured using ambrotype technology. ${ }^{10}$ The negatives for those photographs were printed on glass-slides - a method employed at the Forum until the late 1940's-and placed in individual, sequentially numbered envelopes ("files") in the archives of the Ministry of Cultural Heritage and Activities. ${ }^{11}$ Those sequentially numbered envelopes containing the negatives are organized in binders. As will be seen, there is an ambrotype glass-slide negative and photograph of the Head of Alexander taken in the Museum's cloister, proving it was still in there after 1909.

\section{The Excavation of the Head of Alexander}

9. The Head of Alexander was once part of a series of statues of Parthian "barbarians" (the "Barbarian Statues") decorating the Basilica Emilia's exterior. ${ }^{12}$ See Exhibit 7 for a 3-D model of the Basilica Emilia. ${ }^{13}$ Professor Boni initially ordered the Basilica Emilia to be excavated for only one season (1899-1900), during which excavators discovered several fragments from this series. In 1903, Professor Boni summarized the Basilica Emilia excavations-including the discovery of statue fragments later determined to be part of the Barbarian Statues-for the International Congress of Historical Sciences. See Exhibit 8 (Boni Publication, published 1904). ${ }^{14}$

7. The photographs cannot be precisely dated, but because the photographs detail ongoing excavations, they must have been taken between 1899 and 1900 or in or after 1909 .

8. This document, which accompanies the original application, for reasons of length of the paper does not form part of the present text (editors' note).

9. The images are available at <http://dhc.aarome.org/ search-results?keywords=Basilica + Aemilia $\&=$ Search $>$.

10. Introduced in the 1850's, ambrotype photographs were made using a wet-place, collidion-process variant.

11. The Ministry stores archives in multiple locations that may be accessed only by archival staff.

12. Steppe warriors from the province of Parthia-modern-day Iran and Turkmenistan- Parthians were viewed by Romans as uncivilized "barbarians."

13. This document, which accompanies the original application, for reasons of length of the paper does not form part of the present text (editors' note).

14. This document, which accompanies the original application, for reasons of length of the paper does not form part of the present text (editors' note).
10. During that first season, however, excavators recovered no heads and certainly did not recover the Head of Alexander. In 1903, G. Tognetti-who was present during the 1899-1900 season-wrote a summary of the Basilica Emilia excavation, describing the discovery of several fragments of pavonazzetto marble, and noting -in unambiguous terms - that "[n]one of these fragments of statues has the head or the arms." See Exhibit 9 (Tognetti Summary of Excavation, pg. 10). ${ }^{15,16,17}$ Thus, the contemporaneous record proves that the Head of Alexander could not have been excavated in the initial season from $1899-1900$, because no heads were discovered at this time. And, then, excavations of the Basilica Emilia were suspended until 1909. See Exhibit 10 (Bartoli Publication, dated 1912) ${ }^{18,19}$ wherein Bartoli affirms that excavations resumed two years prior to publication-in other words, during the 1909-1910 season. Thus, no heads could have been discovered at the Basilica Emilia until at least 1909. ${ }^{20}$

11. When excavations of the Basilica Emilia did resume in September 1909, Professor Bartoli began recording the finds in his journal of excavation-again, not assigning unique inventory numbers. See Exhibit 4 (Bartoli Journal). ${ }^{21}$ The first head that appears in the journal is on March 2, 1910: a "[f]ragment of a virile head. Fourth part of the face, from the nose to the top of the forehead. Almost a half larger part of a real one." Id., listing no. 6). Then, on June 12, 1910, archaeologists discovered another "[f]ragment of a virile head. Found at 0.60 [meters] from the ancient ground, about one meter from the column in place (no. 8), but in the back part of this." Id., listing no. 27). While it is not possible to determine with certainty which journal entry and date of discovery correspond to the Head of Alexander, there can be no dispute that the Head must have been excavated after September 1909 during the second phase of excavations. Not only were no Barbarian Statue heads recovered during the 1899-1900 Basilica Emilia

15. [Gustavo Tognetti. "Foro Romano. Appunti sommari sulla Basilica Aemilia". Manuscript (21/05/1903)]. This document, which accompanies the original application, for reasons of length of the paper does not form part of the present text (editors' note).

16. All journal entries are translated from Italian.

17. This document, which accompanies the original application, for reasons of length of the paper does not form part of the present text (editors' note).

18. Alfonso Bartoli. Ultime vicende e trasformazioni cristiane della Basilica Aemilia. Rendiconti della Reale Academia dei Lincei, 21/5 (1912): 758-766.

19. This document, which accompanies the original application, for reasons of length of the paper does not form part of the present text (editors' note).

20. Counsel is correct that during our initial discussions, I indicated that I thought the Head could have been excavated as early as 1899. I pointed out that the investigation was still continuing, but that I wanted to share the early information. As soon as we learned that the Head could not have been excavated that early, I corrected my error. I do not regret providing such open disclosure-Mr. Schoen has proven honorable at every turn.

21. The full title is "Ufficio Scavi: Palatino E Foro Romano, Basilica Emilia Giornale dello scavo in corso," (Office of Excavation: Palatine and Roman Forum, Basilica Emilia Journal of excavation in progress). 
excavations, but the Basilica itself was not excavated again until September 1909, and there are no documented discoveries of heads until March-June 1910.

12. Archaeological evidence also proves that the Head of Alexander must have come from the Basilica Emilia with the other heads excavated in 1910 or later. A fire in late antiquity heavily damaged the Basilica Emilia and left a grey residue on all statues that decorated the building at that time. This residue is visible on the heads remaining at the Roman Forum, as well as on the neck and face of the Head of Alexander. See Exhibit 11 (First Photograph of Head of Alexander) and Exhibit 12A (Photograph of Heads with Black Backdrop). ${ }^{22}$ The evidence of fire damage, therefore, independently establishes that the Head of Alexander must have belonged to the Basilica Emilia decorations and, therefore, must have been excavated after September 1909, most likely in mid-1910 with the other heads from this statue series. ${ }^{23}$

\section{Evidence of the Head of Alexander's Presence in Italy after Excavation}

13. Furthermore, the Head of Alexander was photographed in the Museo Forense after its excavation, as was the standard practice after 1908. The first known photograph of the Head of Alexander is an ambrotype photograph taken on a table against a black backdrop. See Exhibit 11 (First Photograph of the Head of Alexander). That photograph is preserved as a glass-slide negative that is stored in envelope no. 404. See Exhibit 13 (Photograph of Glass-slide Negative and Env. no. 404). ${ }^{24,}{ }^{25}$ Contemporaneously taken photographs demonstrate that this photograph of the Head was taken on a table in the Museo Forense's cloister.

14. Two of those contemporaneous ambrotype photographs are of four heads on the same table and against the same black backdrop as seen in the photograph of the Head of Alexander. Exhibit 12A (Photograph of Heads with Black Backdrop) is taken from the same distance as the photograph of the Head of Alexander, but Exhibit 12B (Photograph of Heads with Cloister Wall) is taken from a wider angle that allows the viewer to see the cloister's stone wall and metal drain above the second head from the left. ${ }^{26}$ It also depicts one of the cloister's windows above the heads to the right. Because the background of the

22. These documents, which accompanies the original application, for reasons of length of the paper do not form part of the present text (editors' note).

23. The identical style of the heads depicted in these photographs is also evidence that the subject Head of Alexander originates from this statue series.

24. The glass-slide negative-used to reproduce the photograph and attached as Exhibit 11-was held at the Archaeological Park of the Colosseum located at Piazza Santa Maria Nova No. 53 in Rome until July 15, 2014, when it was moved to the Palazzo Massimo at Piazza del Cinquecento No. 67 in Rome.

25. This document, which accompanies the original application, for reasons of length of the paper does not form part of the present text (editors' note).

26. These documents, which accompanies the original application, for reasons of length of the paper do not form part of the present text (editors' note). four heads in Exhibit 12A is the background in the photograph of the Head of Alexander, there can be no dispute that the photograph of the Head of Alexander was taken in the Museum's cloister. ${ }^{27}$ Because the cloister was not used until after the Museum's renovation was completed in 1908, the photograph of the Head of Alexander had to have been taken after that year.

15. Thus, all lines of evidence lead to the conclusion that the Head of Alexander was stolen from the Museo Forense in or after 1910. Not only does the written record of excavation prove that the Head of Alexander-undoubtedly from the fire-damaged Barbarian Statue series-could not have been excavated until after September 1909, but the completely independent photographic record also demonstrates with equal clarity that the Head of Alexander was photographed in the Museum's cloister at or about the same time as those heads excavated in $1910 .{ }^{28}$ Regardless of when the Head of Alexander was actually excavated, therefore, it was still present in the Forum complex until at least $1910 .{ }^{29}$

\section{First Crime: Theft of the Head of Alexander}

16. After it's excavation in or about 1910, the Head of Alexander was stolen; it is, however, unknown exactly when. In 1935, the Museo Forense was renamed the Antiquarium Forense, and for the grand opening, antiquities excavated from the Forum-including heads from the Barbarian Statues-were displayed. There are three photographs of the upstairs gallery-believed to have been taken between the end of the Second World War and 1975-that show some of these heads on display. See Exhibit 14A (Photograph Card for nos. 1683 and 1690) and Exhibit 14B (Photograph Card for no. 1689). ${ }^{30}$ But there are no photographs of the Head at the exhibition, no written records indicating whether it was or was not in the 1935 inaugural exhibition, and no subsequent record or photograph of its presence in the Museum. ${ }^{31}$

27. Dr. Fortini has opined that the photographs appear to have been taken in an "impromptu photo studio, probably set up ad hoc at excavation site." She is correct that it was an impromptu photo studio, but her guess that it was "probably" at the excavation site was wrong: it was at the nearby Museum cloister.

28. Dr. Fortini opines that the photographs of heads could have been taken as early as 1899 , but the excavation journals, photographs, and publications prove that no heads were excavated until at least September 1909.

29. The defense's assertion that "there is no competent evidence establishing that the antiquity at issue ever was in the museum where it was purported to have been" (at \17) is not only wrong, but beside the point: whether the Head was stolen from the storage room, the cloister, or the Museum, it was still stolen.

30. This document, which accompanies the original application, for reasons of length of the paper does not form part of the present text (editors' note).

31. Counsel believes I mentioned a photograph of the Head of Alexander with Mussolini taken during the 1935 inaugural exhibition. I take full responsibility for his misunderstanding. I was discussing another investigation in which we did have such a photograph, noting that even if Mussolini himself had 
17. From 1943-1944, staff of the Roman Forum and Palatine Hill prepared a "Prospetto Riassuntivo delle Variazioni" of immovable State property at the site. See Exhibit 15 (Prospectus Summary of Variations, dated 1943-1944). ${ }^{32}$ The document does list "[heads] and fragments of heads such as Alexander Helios (basilica emilia (sic))" valued at 20,000 lire and "[h] eads of barbarians (upper gallery)" valued at 400 lire. Either listing could include our Head, but since there are no photographs or inventory numbers, it cannot be confirmed.

18. In August of 1958, the Department for the Archaeological Heritage of Rome began a de novo inventory of all objects excavated from the Forum that led to the discovery that the Head of Alexander had been stolen. The staff began this inventory by matching photographs of objects excavated at the Forum with objects in the Museum's collection. Each glass-slide negative was removed from its envelope and assigned an inventory number that was entered in a register with other negatives of that format and size. The glass-slide negative depicting the Head of Alexander was listed with other negatives of the same format: A-9x12. See Exhibit 16 (Register Format A-9x12). ${ }^{33}$ This register contains five columns for each object: 1) the date the photograph was entered into the register; 2) the inventory number; 3 ) the number of the envelope containing the photograph; 4) a description; and 5) its value. The inventory numbers reflect the order each glass-slide negative was entered into the register. Some inventory numbers also have an associated "sole" number that groups images by subject, place, or event.

19. Inventory cards were also prepared. A photograph was printed from each glass-slide negative and placed onto cards with the heading "Soprintendenza alle Antichità Palatino e Foro Romano." Each card also has a description of that antiquity (some cards have two photographs), the excavation location, the number of the envelope containing the glass-slide negative, and the inventory number assigned to the photograph.

20. In November 1960, as the inventory continued, Museum staff retrieved the photographic negative of the Head of Alexander from envelope no. 404, assigned it inventory number 5862, and-after searching for the Head in the Museum-realized it was gone. They also noticed that the head depicted in the photograph from envelope no. 403 and assigned inventory number 5861 was missing as well. ${ }^{34}$ Both photographs were a) entered into the register in November 1960 and labeled "lost," see Exhibit 16 (Register Format A-9x12, listing nos. 5861-2, dated Nov. 1960); and b) placed on the same card (Head of Alexander on

removed an object, it was still stolen. To be clear: there is no photograph of the Head of Alexander with Mussolini.

32. This document, which accompanies the original application, for reasons of length of the paper does not form part of the present text (editors' note).

33. This document, which accompanies the original application, for reasons of length of the paper does not form part of the present text (editors' note).

34. Glass-slide negatives 5861 and 5862 are also assigned "sole" number 9873 for "decorative, ideal head." the bottom) with the annotation, "Antiquarium Forense-from the Basilica Emilia: decorative idealized heads (lost)." ${ }^{35}$ See Exhibit 17 (Photograph Card for nos. 5861 and 5862). ${ }^{36}$

21. Thus, it cannot be stated precisely when the Head of Alexander was stolen from the Forum complex prior to the inventory of November 1960. The Head of Alexander could have been stolen between 1910 and the 1935 Museum opening, between the 1935 opening and the Second World War, or after the 1943-44 Prospectus was prepared. Given the size of the Forum and the devastation of two world wars, the uncertainly is not surprising. Nor does it matter. Although the defense contends that the Head's status as stolen property is "based exclusively on [the People's] contention of a post-1909 excavation," at fn. 8, it is actually based exclusively on the Head's removal from the Roman Forum-whenever that was. After all, regardless of when it was stolen (or excavated), it is indisputable that it was removed from the Forum-a theft of property indistinguishable from someone walking into any park, storage locker, or museum in Manhattan and stealing something. The date of excavation is meaningless, the date it entered the museum irrelevant, and the date of theft surplusage.

\section{Illegal Exportation of the Head of Alexander}

22. Additionally, and independent of the theft, the separate act of removing the Head of Alexander from Italy was also illegal-thereby establishing yet another way in which the Head constitutes stolen property under New York law. As is commonplace in the world of illegal antiquities trafficking there is no record of the Head's departure from its country of origin-disappearing until it surfaced on consignment to Sotheby's New York in 1974. ${ }^{37}$ How did it get out of Italy? Silence. Indeed, there is not a single piece of paper documenting anything about the Head of Alexander from its theft and disappearance until its sudden appearance on the New York art market.

23. This lack of any record is not just a testament to the insidious nature of the illegal trade. It necessarily means the Head left the country illegally because, as addressed in the legal section below, the laws regulating the ownership of antiquities from Italy have required government-approved licenses for their exportation since at least June 1909.38 According to the Commander of the Italian Carabinieri Command

35. The defense seems to place great store in the Museum archivist's use of the word "perdute" (lost), but that is exactly the correct pre-investigation word. Now that the investigation has been completed, we may substitute the word "rubato" (stolen).

36. This document, which accompanies the original application, for reasons of length of the paper does not form part of the present text (editors' note).

37. Sotheby's Auction House acquired Parke Bernet Galleries in 1964, and adopted the name Sotheby Parke Bernet in the 1970's. It will be referred to herein as Sotheby's.

38. As discussed in the legal section below, U.S. courts have recognized an even earlier law-enacted in 1902-as vesting ownership of antiquities in the Italian State. 
for the Protection of Cultural Heritage in Rome, however, no license was ever issued for the Head of Alexander authorizing its removal from Italy. See Exhibit 18 (Affidavit from Candido, dated Feb. 22, 2018). ${ }^{39}$ This is not surprising: since June 1909, Italy has never authorized objects from state collections to be exported from the country. If the Head was exported after June 1909, therefore, it was illegal under Italian law. ${ }^{40}$

24. Nor can this conclusion be undermined by speculation that export records might have been destroyed or lost through the passage of time. Even if the two world wars resulted in the destruction of every governmental record in Italy, there would still be a paper trail recording the export, because the original copy of an export permit would have accompanied the Head of Alexander to get it through customs and out of Italy. ${ }^{41}$ Moreover, such a permit-if it existed-would have been preserved by every legal buyer, because it would have exponentially increased the market value of the Head: a legally exported antiquity documented to have come from the Roman Forum would command its own price. Yet, no one has ever produced a permit, receipt, invoice, or shipping document-anything concerning the Head's removal from Italy. No one. Ever. The silence is telling. ${ }^{42}$

25. Thus, because the Head of Alexander was incontrovertibly discovered after the second phase of Basilica Emilia excavations commenced in September 1909 and was photographed thereafter at the Museo Forense, the Head of Alexander must have been exported from Italy after Italy's June 1909 patrimony law prohibiting such export. As will be discussed further in the legal section, under U.S. law, the removal in violation of Italy's exportation laws renders the piece stolen. The Head of Alexander, therefore, constitutes stolen property under New York law by this second theory well.

\section{Post-Italy History: Hagop Kevorkian and Sotheby's}

26. The Head of Alexander-described as a "[m] arble head fragment of Apollo, Roman, c. Late 1st/2nd century A.D., or earlier"-suddenly appeared in 1974 when the Hagop Kevorkian Fund consigned it to Sotheby's for their November 22, 1974, Antiquities

39. This document, which accompanies the original application, for reasons of length of the paper does not form part of the present text (editors' note).

40. To be clear, this Head was excavated from one of the most important archaeological sites in the world. A permit would never be granted.

41. Article 8 of Italian Law No. 364 of June 20, 1909, requires the filing of a report with the export office-meaning that any legal owner or exporter would have had paperwork to prove the export

42. Nor should it be speculated that the Head of Alexander might have been removed from Italy under color of authority. Assuming argumentum ad absurdum, even if Mussolini himself took the Head of Alexander and sold it to a third party, the Head-like many of the works that passed through the hands of Hermann Göring-would still be stolen property because it was not Il Duce's to sell or export.
Auction. ${ }^{43}$ See Exhibit 19 (Sotheby's Catalogue, dated Nov. 22, 1974). ${ }^{44}$ The Fund also consigned the other missing head-the one that appeared in Negative 5861 on the same card as the Head of Alexander-described as a "Roman marble head of Alexander the Great, c. 2nd century A.D., or earlier." 45 At the risk of stating the obvious, that two heads stolen from the Roman Forum suddenly appeared together from the same consignor in the same Sotheby's auction in 1974 can only mean that both the Head of Alexander (Negative 5862/Sotheby's Lot 317) and the head in Negative 5861/Sotheby's Lot 318 were stolen together and remained together until it was deemed safe to sell them publicly. Equally telling, the Hagop Kevorkian Fund has never produced any record of either Head.

27. Nor was Sotheby's any more diligent in its record-keeping, maintaining one document: a 1974 catalogue page with some handwritten notes scribbled on it. See Exhibit 20 (Sotheby's Catalogue, Annotated). ${ }^{46}$ Sotheby's has nothing about the provenance of the Head before consignment. Nor does the catalogue mention Italy. If Kevorkian or his Fund had legally acquired the Head (although neither could have), that information would certainly have been passed to Sotheby's and advertised in the 1974 catalogue to boost the Head's value. The absence of any records or country of origin can only be explained by the fact that Sotheby's did not ask and Kevorkian did not tell.

28. According to its scribbled notes, Sotheby's estimated the Head would sell for “\$1250-1750," but it actually sold for " $\$ 650.00$ " to "Altertum Ltd." Therein lies another problem: there is no record of this company ever having been registered in the United States-or anywhere else. Since Altertum is German for "antiquity," this Office contacted colleagues in the German Bundeskriminalamt's Art and Antiquities section. According to them, Altertum Ltd. has never existed in Germany. According to the Art and Antiquities Unit of London's Metropolitan Police, there has never been a company called Altertum Ltd. registered in the United Kingdom either. In fact, Altertum Ltd. does not appear anywhere-not in the acquisition records of the British Museum, the catalogues of the Berlin or Heidelberg art libraries, or the Getty Research Institute's Primo Search Provenance database. Given that there are no records of this company or its purchase, the conclusion is obvious: this was a classic straw purchase designed to launder the Head by creating a documented history (the catalogue) in order to camouflage the illegal history and increase its future value. ${ }^{47}$

43. An Armenian archaeologist and collector, Hagop Kevorkian (1872-1962) established the Fund in 1951.

44. This document, which accompanies the original application, for reasons of length of the paper does not form part of the present text (editors' note).

45. Confusingly, Sotheby's listed the stolen Head of Alexander in its catalogue as a "marble head fragment of Apollo" and the second stolen head as a "Roman marble head of Alexander the Great."

46. This document, which accompanies the original application, for reasons of length of the paper does not form part of the present text (editors' note).

47. Another possibility-that Altertum Ltd. was established as an offshore company for a single sale and then immediately dissolved-raises the same problematic specter. 
29. To date, no one has ever produced any records for any pre-1974 transaction for the Head of Alexander. Nor has anyone ever produced any records for the 1974 sale by Sotheby's to "Altertum Ltd." Nor has any party ever produced an export visa or stamp authorizing the Head's removal from Italy. No bill of lading. No transportation documents. No insurance documents. No customs declaration for the Head. No mention of the Head in a will. In short, no written record of any kind.

30. The timing of the sale is also alarming. In 1974, Sotheby's knew the importance of provenance because the U.S. had just ratified the 1970 UNESCO Convention on the Means of Prohibiting and Preventing the Illicit Import, Export, and Transfer of Ownership of Cultural Property. ${ }^{48}$ The Convention set 1970 as the baseline for documenting ownership history, thereby putting dealers, auction houses, collectors, and museums on notice that starting in 1970 , 1) all transfers should be documented and 2) all buyers should seek provenance before purchasing an object. Yet, Sotheby's has no record of doing either. Following the "sale" to phantom Altertum Ltd., the Head disappeared again for 37 years.

31. The Head resurfaced in 2011, once again on the Sotheby's auction block. In 2011, Dr. Martin C.J. Miller consigned the Head to Sotheby's for its December 8, 2011, "Egyptian, Classical, and Western Asiatic Antiquities Auction." ${ }^{49}$ See Exhibit 21 (Sotheby's Catalogue Lot 9, dated Dec. 8, 2011)..$^{50}$ Notably, Sotheby's 2011 catalogue included new pre-1974 provenance: "Hagop Kevorkian (1872-1962). New York, most likely acquired prior to World War II." When Sotheby's sold the Head in 1974, the only history they printed was "Property of the Hagop Kevorkian Fund." But in 2011, they added "most likely acquired [by Hagop Kevorkian] prior to World War II." Sotheby's has never explained the source of this additional information or produced any documentation supporting it.

32. This new information could not have come from their records: in 2018, Sotheby's produced 11 pages related to the 2011 consignment: two were blank, two were statements, three were instructions for payment, two were copies of the 2011 catalogue entry, one was the cover of the 2011 catalogue, and one was the 1974 catalogue entry. See Exhibit 22 (Sotheby's Documents Related to Dec. 8, 2011 Auction). ${ }^{51}$ As with the 1974 sale, there is no document about its history. Nor did they get the information from the consignor. According to Dr. Miller, he had been bequeathed the Head in 1988 by Alcibiades Nikolaeos

48. The United Nations Educational, Scientific, and Cultural Organization.

49. Dr. Martin C.J. Miller, an Associate Professor of History at Metropolitan State College of Denver from 2000-2005, is the Executive Editor of The Ancient World: A Scholarly Journal for the Study of Antiquity.

50. This document, which accompanies the original application, for reasons of length of the paper does not form part of the present text (editors' note).

51. This document, which accompanies the original application, for reasons of length of the paper does not form part of the present text (editors' note).
Oikonomides-who told Dr. Miller that he purchased the Head of Alexander while vacationing in Egypt. ${ }^{52}$

33. Thus, forty years after the landmark $1970 \mathrm{UN}$ ESCO Convention, Sotheby's accepted on consignment an antiquity that had no documentation whatsoever about its provenance, ownership history, country of origin, or legality, obscuring this absence with the new words "most likely acquired prior to World War II." The cover-up worked: in 2011, with new provenance, Sotheby's sold the Head to Mr. Saad Abdulla Shartub Al-Dehaimi of Doha, Qatar, for $\$ 75,000$. See Exhibit 25 (Invoice, dated Aug. 19, 2013). ${ }^{33,54}$

34. In May 2017, the Head of Alexander surfaced in the United Kingdom in the possession of the Sheikh Saoud bin Mohammed Ali Al-Thani Foundation. A former Qatari official, Al-Thani had been appointed in 1997 by the Cultural Ministry in Qatar to obtain art for their national collections. But in 2005, he was placed under house arrest for conspiring with London-based dealer Oliver Hoare to create grossly inflated invoices for objects he was buying for the Qatari government, pocketing the difference, and then using State funds to purchase objects for his personal collections. ${ }^{55}$ On May 24, 2017, his foundation consigned the Head of Alexander to Classical Galleries Limited, UK. See Exhibit 26 (Invoice, dated May 24, 2017). ${ }^{56}$

35. In June 2017, while the Head of Alexander was consigned to Classical Galleries, Safani requested a search of the Art Loss Register (ALR) database to determine if the Head had ever been reported stolen. The Head of Alexander did not appear in the ALR database, and Safani received a certificate to that effect-meaning simply that the Head had not been reported as stolen to the ALR. See Exhibit 27 (ALR

52. Dr. Oikonomides (d. 1988) was a Classics professor at Loyola University and an art collector. Prior to his death, he worked with Dr. Miller on the journal The Ancient World: A Scholarly Journal for the Study of Antiquity. He must have acquired the Head by 1981, because he included a photograph of it on the cover of The Ancient World's issue entitled Alexander the Great I (Volume 4). See Exhibit 23 (Oikonomides Publication, 1981). In 2012, Dr. Miller wrote in "Alexander Helios in Chicago," The Ancient World, Volume XLIII, no. 1, that " $t]$ he head was purchased on November 22, 1974 from the Hagop Kevorkian Fund by Al. N. Oikonomides of Chicago. The Fund did not provide any record as to how, when or from where the head originated." See Exhibit 24 (Excerpt from Miller Publication, 2012). These documents, which accompanies the original application, for reasons of length of the paper do not form part of the present text (editors' note).

53. The sale date is listed as December 8, 2011, but the document is dated August 19, 2013.

54. This document, which accompanies the original application, for reasons of length of the paper does not form part of the present text (editors' note).

55. The Qatari government eventually dropped the charges but dismissed him from their employ. He lived in London until his death in November 2014.

56. This document, which accompanies the original application, for reasons of length of the paper does not form part of the present text (editors' note). 
Certificate, dated Jun. 6, 2017). ${ }^{57,58}$ Nor was the Head of Alexander present in the Carabinieri's Banca Dati or Leonardo databases-two listings of stolen objects maintained by Italian law-enforcement. As with the ALR, the Carabinieri are reliant on affirmative reporting: if a theft is not reported directly to them, the object will not be in their databases. Nor did its appearance in Sotheby's 2011 catalogue or on their website alert the Carabinieri to investigate the Head, since Sotheby's catalogue conveniently never listed the country of origin. ${ }^{59}$

\section{Safani Gallery \& Seizure of the Head of Alexander}

36. On June 20, 2017, Safani Gallery purchased the Head of Alexander from Classical Galleries for $\$ 152,625.00$, see Exhibit 28 (Invoice, dated Jun. 20, 2017), ${ }^{60}$ and it arrived in New York on August 7, 2017. See Exhibit 29 (Customs Entry Form, dated Aug. 16, 2017). ${ }^{61}$ Then, in the fall of 2017, Safani contacted Maud Leclair, now at the Metropolitan Museum of Art, for assistance in investigating his new acquisition's provenance. On November 1, 2017, the Hagop Kevorkian Center for Near-Eastern Studies at New York University informed Leclair that Kevorkian's "personal papers, If (sic) there are any preserved, could potentially be with the Kevorkian Fund, which may now be dissolved. Unfortunately we don't really have contact with them and I have no information to pass along." See Exhibit 30 (Email to Leclair, dated Nov. 1, 2017). ${ }^{62}$ Given its dissolution, however, the Fund was unreachable.

37. Safani then exhibited the Head at The European Fine Art Fair's (TEFAF) Fall 2017 show in New York in October 2017, listing its most recent possessor as "Private English Collection 2012-2017." See Exhibit 32 (Summary Document). ${ }^{63}$ After it did not sell in New York, Safani prepared to offer it at the TEFAF art

57. A commercial company established in London in 1991 , the ALR may have the largest private database of lost and stolen art-stressing, however, that its "database does not contain information on illegally exported artefacts unless they have been reported to us as stolen...[and]... Not every loss or theft is reported to us."

58. This document, which accompanies the original application, for reasons of length of the paper does not form part of the present text (editors' note).

59. Identifying the head as "Roman" would not alert Italian authorities to conduct a search. Given the size of the Roman Empire and its extensive trade, a "Roman" antiquity might have been looted from several dozen modern nation states throughout Europe, North Africa, and the Middle and Far East.

60. This document, which accompanies the original application, for reasons of length of the paper does not form part of the present text (editors' note).

61. This document, which accompanies the original application, for reasons of length of the paper does not form part of the present text (editors' note).

62. This document, which accompanies the original application, for reasons of length of the paper does not form part of the present text (editors' note).

63. This document, which accompanies the original application, for reasons of length of the paper does not form part of the present text (editors' note). fair in Maastricht to take place in March 2018. See Exhibit 33 (TEFAF Advertisement, dated Mar. 2018). ${ }^{64}$ 38. On February 19, 2018, in what can only be described as extraordinary attention to detail-and serendipity - a member on Dr. Fortini's staff saw Safani's TEFAF Maastricht advertisement and matched it to the Head stolen long-ago from the Roman Forum. Dr. Fortini immediately notified the Carabinieri. ${ }^{65}$ See Exhibit 34 (Theft Report, dated Feb. 19, 2018) and Exhibit 35 (Theft Report, dated Feb. 22, 2018). ${ }^{66}$ On the following day, February 20, 2018, the Carabinieri notified me of Dr. Fortini's report, and two days after that, I received formal notification from the Italian government that the Head of Alexander was stolen, and this Office received a warrant to seize the Head of Alexander ${ }^{67}$ See Exhibit 36 (Search Warrant for Safani Gallery, dated Feb. 22, 2018). ${ }^{68}$ The Head of Alexander remains safely with this Office.

\section{LEGAL ARGUMENT}

39. There are three legal issues: 1) this court's authority to adjudicate ownership; 2) whether the Head of Alexander constitutes stolen property; and 3) whether a hearing is necessary.

\section{This Court's Authority Under PL §450.10: People ex rel. Simpson Co. v. Kempner}

40. On October 27, 2017, pursuant to a search warrant issued by the Honorable Melissa C. Jackson, this Office seized, from U.K.-based dealers Rupert Wace and Sam Fogg, a Persian Guard Relief that had been stolen from Persepolis. After being notified under PL $\S 450.10$ of our intention to return the Relief to Iran, Wace and Fogg filed motions in opposition. On December 18, 2017, Judge Jackson ruled that, under People ex rel. Simpson Co. v. Kempner, 208 NY 16 (1913), the court did not have jurisdiction to determine the issue of ownership since no criminal prosecution was pending against Wace or Fogg and

64. This document, which accompanies the original application, for reasons of length of the paper does not form part of the present text (editors' note).

65. The delay between the initial discovery of the theft in 1960 and Dr. Fortini's report of February 19, 2018, is irrelevant, but easily explained: Dr. Fortini did not learn of the Carabinieri's database until February 2018.

66. After the initial Application, the People received certified translations correcting errors in the original translations. Exhibits 34 and 35 are those corrected translations. Additionally, Dr. Fortini opines on February 22, 2018 that the Head was likely stolen between 1935 and November 1960-and she may well be correct-but this Office has not uncovered conclusive evidence that the Head was still in the Forum complex in 1935. (These documents, which accompany the original application, for reasons of length of the paper do not form part of the present text [editors' note]).

67. The defense's claim that the agents "videotaped the entire premises" (at $\$ 4$ ) is inaccurate. The agent did take photographs in the one-room gallery-a sound practice for potential future proceedings.

68. This document, which accompanies the original application, for reasons of length of the paper does not form part of the present text (editors' note). 
none was forthcoming. But in ruling that ownership should be determined in "a more appropriate forum, such as a court with civil jurisdiction," Judge Jackson affirmed the use of the search warrant to seize the Relief, directing this Office, under PL §690.55(1)(b), to retain the Relief pending resolution of its ownership. ${ }^{69}$ In citing the Judge Jackson case, moreover, the defense here failed to mention that seven months later, on July 23, 2018, the Judge ordered the Relief to be returned to Iran pursuant to PL \$450.10. In other words, the Judge affirmed her authority under PL $\$ 450.10$ to adjudicate the release of stolen property. ${ }^{70}$ The Relief has since been returned to Iran.

41. Kempner is inapplicable. First, Kempner was decided in 1913 under a former statute that has since been corrected and replaced. Second, criminal term does have civil jurisdiction to decide the question of ownership. Third, in 1999, the Court of Appeals held that PL $\$ 450.10$ does provide a mechanism for ownership disputes. And, fourth, Kempner was limited to cases that are "of no direct concern to the state." At 25.

42. In Kempner, a maid stole two diamond rings from her employer and sold them to a pawnbroker-from whom they were seized pursuant to a search warrant. The maid was never arrested, and the pawnbroker was never charged. After the pawnbroker was notified that the court would determine the owner, the pawnbroker asserted ownership. The Court of Appeals held that N.Y. Code Crim. Proc. \$687-the predecessor to the current PL \$450.10-violated constitutional due process by not providing notice and an opportunity to be heard. ${ }^{71}$ Thus, because the statute was infirm and because the dispute between the owner of the rings and the non-party pawnbroker bore "no direct concern to the state," the Court ruled that the issue of ownership had to "be determined in a civil action, in which the parties are by Constitution entitled to notice and a hearing and, if demanded, to a trial of the issue by a jury." Id.

43. First, since then, §687's shortcomings have been corrected and replaced by PL $\$ 450.10$. Not only does PL §450.10(1) mandate that notice be provided, but once a criminal court takes custody of the property, PL \$450.10(5) requires that same criminal court to preside over the property's return to the owner: "[i] $\mathrm{f}$ stolen property comes into the custody of a court, it must...be delivered to the owner...certified by the court." In other words, the plain language of the current statute is that "the court" that has custody of the property is "the court" that must certify the ownership of the property. Indeed, having the criminal

69. It is unclear why counsel finds it "troubling" (at 99) that the People brought the Head of Alexander search warrant to this court. Not only did Judge Jackson affirmed the use of the search warrant in the Relief case, but it was the Administrative Judge who assigned this investigation to this court.

70. Wace and Fogg also executed a stipulation consenting to the return.

71. Under \$687, "[i]f property stolen or embezzled comes into the custody of a magistrate, it must, unless its temporary retention be deemed necessary in furtherance of justice, be delivered to the owner, on satisfactory proof of his title...to be certified by the magistrate." court determine the ownership of the stolen property is precisely why PL $\$ 450.10$ was enacted in the first place: to "enable[] victim[s] of a larceny...to have his or her property returned much more quickly than [was] possible on the [then] existing law." See Memorandum of Assemb. Stephen M. Saland, Laws 1984, ch. 795, published in New York State Legislative Annual, 1984, p. 264 (1985). Civil court delays are, after all, legendary.

44. Since then, release under PL $\$ 450.10$ has become commonplace. See, e.g., Stuhler v. State, 127 Misc. 390, 393-94 (NY County 1985), wherein the court, citing its authority under PL $\$ 450.10$, directed the Attorney-General to return to the 144 victims the $\$ 250,000$ seized from defendants pursuant to a search warrant: "Penal Law § 450.10...governs the disposal of stolen property...It authorizes the court to deliver or order the delivery of stolen property to the owner, on proof of title." See also Okada v. Property Clerk of the Police Dept of N.Y., Lexis 292 (NY County 2004) (court ordered stolen violin returned to owner over objection of this Office and NYPD Property Clerk that there might be additional claimants). The court held that it was authorized under PL $\S 450.10$ to determine the issue of ownership. Insisting that PL §450.10's notice period be observed, the court required the owner of the violin, who had already waited nearly 10 years for it return, to wait fifteen more days. Here, Safani received notice ten months ago. See Exhibit 37 (450.10 Release Notice, dated Feb. 22, 2018). ${ }^{72}$

45. Second, criminal courts do have civil jurisdiction, and the CPL recognizes this duality:

[A] court specified herein which possesses civil as well as criminal jurisdiction does not act as a criminal court when acting solely in the exercise of its civil jurisdiction, and an order or determination made by such a court in its civil capacity is not an order or determination of a criminal court even though it may terminate or otherwise control or affect a criminal action or proceeding.

\section{CPL §10.10[7]. So does the Court of Appeals:}

[A] motion to quash subpoenas, even those issued pursuant to a criminal investigation, is civil by nature and not subject to the rule restricting direct appellate review of orders in criminal proceedings...there may be a variety of reasons why a particular [civil] matter is assigned to a Criminal Term of the Supreme Court, not the least of which may be that the matter requires prompt attention, but because of a backlog of other civil matters no other parts are available.

In re Abrams, 62 N.Y.2d 183 (1984). See also People v. Santangelo, 38 N.Y. 2d 536 (1976) (motions to quash subpoenas in criminal court are civil in nature); Cunningham v. Nadjari, 39 N.Y. 2d 314 (1976) ("orders [on] motions to quash subpoenas in criminal investigations...were final orders in special proceedings on the civil side of a court vested with

72. This document, which accompanies the original application, for reasons of length of the paper does not form part of the present text (editors' note). 
civil jurisdiction"); and In the Matter of the People \& c., v. Conrado Juarez and Frances Robles, Slip Op., 58 (June 27, 2018) (motions to quash subpoenas prior to filing of accusatory instrument are civil in nature and those that occur after filing are criminal in nature and not subject to appeal).

46. Third, in 1999, the Court of Appeals affirmed the use of PL $\$ 450.10$ "for returning allegedly stolen property to an owner prior to, or during the pendency of, a criminal proceeding." People v. Museum of Modern Art (In re Grand Jury Subpoena Duces Tecum), 93 N.Y. 2d 729, 740 (1999). In that case, the court quashed this Office's subpoena on the grounds that Arts and Cultural Affairs Law \$12.03 prohibited the seizure by subpoena of art on a traveling exhibit. But the court's ruling on PL $\$ 450.10$ is dispositive here. Had the painting been properly seized (by warrant, not subpoena), then

Penal Law \& 450.10, which provides a mechanism for returning allegedly stolen property to an owner prior to, or during the pendency of, a criminal proceeding, requires proof of title before property in the custody of the People or the court can be returned. Thus, a civil-like proceeding would have to be commenced in this case to return the paintings to the rightful owners under either CPL $\$ 610.25$ (2) or Penal Law $\$ 450.10$ regardless of the outcome of the People's case.

Id. In other words, the Court implicitly over-ruled Kempner and unambiguously held that a) prior to or during a criminal proceeding; b) the court in this case must conduct a civil-like proceeding; c) under PL $\S 450.10$ (or CPL $\S 610.25$ if a subpoena was at issue).

47. "[P]rior to, or during the pendency of, a criminal proceeding." Notably, neither the statute nor the Court of Appeals requires an accusatory instrument to trigger the warrant-issuing court's authority to return property to the rightful owner pursuant to PL §450.10. That is because CPL §1.20[18] defines "Criminal Proceeding" as "any proceeding which (a) constitutes a part of a criminal action or (b) occurs in a criminal court and is related to a prospective, pending, or completed criminal action, either in this state or of another jurisdiction, or involves a criminal investigation." In other words, PL $§ 450.10$ is the mechanism for returning stolen property to its owner at any point in a criminal investigation. Because the seizure of the Head of Alexander was based on, and remains, a criminal investigation, the determination of the Head of Alexander's ownership is indisputably a "criminal proceeding" and PL $\$ 450.10$ applies. ${ }^{73}$

48. "[A] civil-like proceeding would have to be commenced in this case...under...[PL] \$450.10." Having issued the warrant in this case, the court in this case must conduct a civil-like proceeding to determine ownership. There is, of course, nothing terribly novel about criminal courts conducting civil-like proceedings. A non-exhaustive list would include restitution hearings; civil-forfeiture actions; confessions of judgment; record-sealing proceedings (People v. M.E., 121 A.D. 3d 157 (4th Dept. 2014)); issuance of supplemental orders (People v. Purley, 297 A.D. 2d 499 (1st Dept.

73. Given all of the New-York-based actions in 2011 and thereafter, this investigation remains open.
2002); and certain civil-commitment proceedings (New York State Dept of Mental Hygiene v. County of Broome, 89 Misc. 2d 354 (Broome County 1977)). Similarly, the Integrated Domestic Violence part hears related criminal and civil matters simultaneously. ${ }^{74}$

49. Indeed, New York has long rejected initiating separate civil actions for the return of property that has been seized pursuant to a warrant. See, e.g., In the Matter of Documents Seized Pursuant to a Search Warrant, 124 Misc. 2d 897, 898-99 (Sup. Ct., New York County, 1984), where the defendant-business owner petitioned the warrant-issuing court for the return of documents that had been seized by this Office and given to civil agencies. In ordering the return of the documents, the court held that under "long usage," the warrant-issuing court has exclusive authority over the return of property. See also People v. Louis Posner, 86 A.D. 3d 443 (1st Dept 2011) (affirming the criminal court's authority to release funds seized pursuant to a search warrant to pay the defendants' attorneys' fees and living expenses); People v. Braunhut, 101 Misc. 2d 975, 981 (Bronx County 1979) ("The local criminal court possesses the requisite jurisdiction to order the release of property...It is the court most familiar with the facts of the case, and should not be reluctant to exercise its jurisdiction").

50. Thus, by statute, by policy, and by long and daily usage, the Court of Appeals' determination in Museum of Modern Art that the criminal term is the appropriate forum to determine the question of ownership PL $\$ 450.10$ has been proven correct. ${ }^{75}$

51. Fourth, and finally, by its own language, Kempner was limited to cases that are "of no direct concern to the state." Unlike in Kempner, New York State has the same overriding interest in the Head of Alexander that it has in all antiquities sold through New York's robust art markets-arguably the most lucrative and comprehensive in the world: that the market be honest and law-abiding. See, e.g., Kunstsammlungen $\mathrm{Zu}$ Wiemar v. Elicofon, wherein the Weimar Museum sought to recover paintings in New York that had been stolen from Germany during the Allied occupation. 536 F. Supp. 829, 846 (E.D.N.Y. 1981) (case of direct concern to New York "as a means to preserve the integrity of transactions and in preventing the state from becoming a marketplace for stolen goods").

52. After all, New York is home to many millions of dollars spent annually on the sale of art and antiquities. In addition to creating tax revenue for the city's

74. Nor does it matter that the precise procedure to be followed in a PL $\$ 450.10$ hearing is left to the discretion of the criminal court-just as it is in Ventimiglia hearings, Sandoval hearings, etc. The Court of Appeals informs criminal courts when hearings are necessary and leaves it to those courts to determine how to conduct such hearings-whether those hearing are "criminal" or "civil" in nature.

75. Nonetheless, the defense suggests that a criminal court is divested of jurisdiction whenever the matter is disputed or difficult. But no statute in the penal law or judge in the system is limited to uncontested or easy cases. Similarly puzzling is any suggestion that Safani has good title because he has not been charged. Every crime has multiple elements. That the People may not be able to prove the mens rea here, does not cleanse the stolen Head of its illegality. 
coffers, New York's art market draws large numbers of people to New York every year and enhances New York City's reputation as an international cultural mecca. Thus, New York courts have an undeniable interest in denying safe haven to possessors of stolen cultural property. See, e.g., Bakalar v. Vavra, 619 F.3d 136 (2010), aff'd, 500 F. Appx. 6 (2d Cir. 2012), wherein a 1917 drawing by Egon Schiele had been stolen from a cabaret performer (who was murdered by Nazis in 1941) and subsequently purchased by a Swiss gallery before landing in a New York gallery. The court noted that, although the piece was purchased in Switzerland by a Swiss gallery, New York's interest controlled. See also a recent case involving a Modigliani painting that had been looted in Europe during the Nazi genocide: "New York does NOT permit a thief to pass good title to a painting and has a vested interest in ensuring stolen works of art do NOT enter its stream of commerce." (Emphasis in original). ${ }^{76}$ Here, the stolen Head of Alexander was possessed and offered for sale in New York County, and its recovery is of direct concern to the state.

\section{Stolen Property: A Thief Can Never Acquire Good Title in New York}

53. "New York case law has long protected the right of the owner whose property has been stolen to recover that property, even if it's in the possession of a good-faith purchaser for value." Solomon $R$. Guggenheim Foundation v. Lubell, 77 N.Y. 2d 311, 317 (1991). See also Bakalar v. Vavra, 619 F.3d at 136 ("a thief cannot pass good title in New York") and PL \$155.00(5) ("owner" of property "is any person who has a right to possession thereof superior to that of the taker, obtainer or withholder"). Depetris v. Warnock, 2000 N.T. Misc. LEXIS 428, 2 (Just. Ct. Mar. 21, 2000), is particularly illustrative. Warnock's watch was stolen and sold to a pawnbroker who resold it to Depetris, a collector of fine watches. After the original thief was convicted, the Assistant District Attorney had the watch returned to the original owner (Warnock); but the collector (Depetris) sued to get it back, claiming he had acquired title under the Uniform Commercial Code. The court held that "[w] hen the thief sold the watch to the pawnbroker, the thief did not have title to sell. The pawnbroker did not acquire title." Id. See also Candela v. Port Motors, 208 A.D.2d 486 (2nd Dept. 1994) (neither a thief, nor a successor of a thief, can convey good title to a subsequent purchaser). Thus, the original thief here-as in all thefts-had no title to pass anyone, including Safani.

76. George W. Gowen as Limited Ancillary Administrator of the Estate of Oscar Stettiner vs. Helly Nahmad Gallery, Inc., Helly Nahmad, (New York), individually, David Nahmad, and International Art Center S.A.). See also PL \$165.60(3) (it is not a defense that the theft did not occur within the State) and PL §165.60(1) (it is not a defense that the person who stole the property has not been convicted, apprehended, or identified).

\section{Stolen Antiquities under International Law}

54. As has already been seen, the first international attempt to prevent the trafficking of illegal cultural property was UNESCO's 1970 Convention. Ratified by 130 countries (including the U.S. in 1972), it requested countries to prohibit the importation of property that was illegally exported from other countries. $^{77}$ To be clear, the People do not cite the UNESCO Convention as a legal basis to determine that the Head of Alexander is stolen. Rather, it is cited because beginning in 1970, the Convention put the entire antiquities community on notice that any unprovenanced antiquity that appears on the market after 1970 is likely illegal and, therefore, necessitates further research.

\section{Stolen Antiquities Under Federal Law}

55. Federal law is in accord: under the National Stolen Property Act ("NSPA"), it is a criminal offense to transport or receive in interstate commerce any goods knowing they are stolen. ${ }^{78} 18$ U.S.C.A. $\$ \$ 2314-$ 15. In United States v. McClain, 545 F.2d 988 (5th Cir. 1977), the court considered whether pre-Columbian artifacts exported in violation of Mexico's customs laws could be considered "stolen" under the NSPA. ${ }^{79}$ The Court held that under U.S. law, "illegal exportation constitutes a sufficient act of conversion to be deemed a theft." Id. at 1003. This "theft," coupled with "a declaration of national ownership therefore suffices to render an illegally exported item 'stolen'." $I d$. at 1001. In other words, if an antiquity is removed from its country of origin after the effective date of that country's applicable patrimony law, and such removal is in violation of that country's exportation laws, then the wrongfully exported antiquity constitutes "stolen property." Thus, although the crime of wrongful exportation from the country of origin does not constitute a separate crime under our law, such wrongful exportation does render the antiquity "stolen property" under New York State Penal Law \$155.00 et seq. See also United States v. Schultz, 333 F.3d 393 (2d Cir. 2003) (antiquities dealer convicted of smuggling antiquities out of Egypt in violation of Egypt's patrimony law designating all antiquities discovered after 1983 to be property of the state). The Schultz court expanded McClain, holding that a defendant may not evade liability by arguing he did not know foreign law had made the exportation illegal. Taken together, in what has come to be called the McClain-Schultz

77. In response, the U.S. enacted the Cultural Property Implementation Act of 1983, placing the initial burden of proving the lawful possession of an artifact on the possessor.

78. As with the UNESCO Convention, the People do not introduce the NSPA as a legal basis for determining that the Head is stolen-only to contextualize the definition of stolen property under New York law.

79. The Court reversed the conviction of the four defendants on the substantive count charging a violation of the NSPAfinding that Mexico's 1897 laws were not sufficiently clear-but affirmed the conspiracy conviction because the acts underlying that count were clearly illegal under either Mexico's less-clear 1897 or sufficiently clear 1972 law. 
doctrine, if an unauthorized exportation takes place after the effective date of a country's patrimony law the object constitutes stolen property-whether the defendant knew of the patrimony law or not.

\section{Stolen Antiquities under New York Law}

56. As set forth in detail above, under New York law, the Head of Alexander constitutes stolen property because it was "wrongfully take[n], obtain[ed], or with[e]ld from an owner thereof," PL §155.00(1), with the "owner" being "any person [i.e., Italy] who has a right to possession thereof superior to that of the taker, obtainer or withholder." PL §155.00(5).

57. The Head also constitutes stolen property under the McClain-Schultz doctrine, because it was illegally exported from Italy. According to Leila A. Amineddoleh, an expert in Italian law who is also a professor of art law at Fordham University School of Law and New York University, the first antiquities law governing modern Italy is Law No. 185 of June 12, 1902. Article 1 of the 1902 law states that the law applies to objects that have archaeological value. Article 2 states that antiquities belonging to public buildings are inalienable, and Article 3 states that antiquities under Article 2 may be alienated only to the state or state-owned entities upon authorization of the Ministry. Moreover, Article 25 states that all sales made in violation of Articles 2 and 3 are void. In U.S. v. An Antique Platter of Gold, 184 F.3d 131, 134 (2d Cir. 1999), the court examined Article 44 of Italy's law of June 1, 1939, No. 1089, and held that "[t]he presumption is that the object belongs to the Italian state unless a possessor is able to prove private ownership prior to 1902."

58. The 1902 law was expanded on June 20, 1909, Law No. 364, to vest ownership in the state of all antiquities found within the borders of Italy since 1909. This 1909 law was expanded in 1939, Law No. 1089, to include all "moveable and immovable things of artistic, historic, archaeological or ethnological interest." The law continues under the new Code of Cultural Property and Landscape enacted in 2004. U.S. courts have recognized the 1902 law to vest ownership of antiquities in the Italian state.

59. Again, the Head never received a permit. Article 5 of the 1909 law also establishes that it is illegal to transfer property or title to property without notifying governmental authorities. No one ever made such a notification. Finally, Article 8 of the 1909 law provides that "[t]he exportation from the Kingdom of items that are of historic, archaeological or of artistic interest, is prohibited when their export constitutes a serious harm to the history, archaeology or the fine arts." At the risk of stating the obvious, and according to the representatives of the Italian government previously cited, the Head of Alexander, from the most important site in Rome, is an object of historic interest whose export represents a serious harm to the history and archaeology of Italy. The effective date of Italy's patrimony law as it applies to the Head of Alexander, then, is June 1909 at the latest. But the earliest possible excavation date of the Head was September 1909. Thus, even if it were exported the same day it was photographed in the museum cloister, its exportation was necessarily illegal. Moreover, the more applicable effective date would be June 1902, more than seven years before the Head's earliest possible excavation.

60. In opposition to the current application, the defense here quotes U.S. v. Mask of Ka-Nefer-Nefer, LEXIS 47012 (E.D. Mo., March 31, 2012), that "the government cannot seek forfeiture on the basis of a 'bold assertion that because something went missing from one party in 1973 and turned up with another party in 1998, it was therefore stolen and/or imported or exported illegally." At 951. This partial quote is misleading, however, because the full quote shows that the court was not commenting on the propriety of the law at all. Rather, the court noted that,

The Government cannot simply...initiate a civil forfeiture proceeding on the basis of one bold assertion that because something went missing from one party in 1973 and turned up with another party in 1998, it was therefore stolen and/or imported or exported illegally. The Government is required under the pleading standards set forth in the Federal Rules of Civil Procedure to provide specific facts, or plead "with such particularity."

61. In other words, the court ruled that the Government's pleadings were insufficient. Nothing more. See Exhibit 38 (U.S. v. Mask of Ka-Nefer-Nefer Complaint, dated Mar. 16, 2011). ${ }^{80}$ The rebuke was proper: not only did the complaint fail to state whether it was charging theft or illegal exportation, but it "completely failed to identify...the established law that was violated when the Mask was...purportedly stolen from Egypt." $I d$. Here, the facts [of the original application in its unedited form] cover 18 pages and the law another 13 pages. The Mask of Ka-Nefer-Nefer, therefore, is inapplicable here.

\section{Statute of Limitations}

62. Any prosecution for criminal possession of stolen property as a felony "must be commenced within five years after the commission thereof." CPL $\$ 30.10(2)(b)$. Criminal possession of stolen property is, of course, a continuing crime. Since "the Statute of Limitations of a continuous crime is governed by the termination and not the starting date of the offense," People v. Eastern Ambulance Service, Inc., 106 A.D.2d 867, 868 (4th Dept 1984); see, also, People v. DeBeer, 35 A.D.3d 1275 (4th Dept 2006), the five-year statute of limitations as applied to the Head of Alexander does not expire until February 22, 2023. ${ }^{81}$

80. It is crucial to note that the 8th Circuit affirmed only the procedural ruling (dismissing the case because the Government failed to file a timely amendment to its complaint), and declined to address the propriety of the seizure of "ancient artifacts": "[w]e affirm the district court's procedural ruling and leave this important substantive issue for another day." U.S. v. Mask of Ka-Nefer-Nefer 752 F.3d 737, 738 (8th Cir 2014). (This document, which accompanies the original application, for reasons of length of the paper do not form part of the present text [editors' note]).

81. The defense claims that "under Italian law, the piece at issue could not have the legal status of stolen property for purposes of Italian criminal law as a matter of law, for the 


\section{A Hearing is Unnecessary ${ }^{82}$ CONCLUSION}

63. The Head of Alexander was excavated from the Basilica Emilia in the Roman Forum after September 1909 and then stolen from a state-owned collection (the theft). It was thereafter illegally exported from Italy after the enactment of Italy's patrimony law of June 12, 1902 (the illegal exportation). The Head of Alexander, therefore, constitutes stolen property under New York law and belongs to Italy.

64. Under CPL $\$ 690.55(1)$, only the warrant-issuing court may determine the Head of Alexander's ultimate disposition. Simpson v. St. John, 93 N.Y. 363, 366 (1883) (property seized pursuant to a court order "cannot be taken away until that custody is ended by...an order of the magistrate permitting its surrender to the owner"). And, under PL §450.10(5), the warrant-issuing court must deliver the demanded property to the owner, "on satisfactory proof of his title." People v. Museum of Modern Art (In re Grand Jury Subpoena Duces Tecum), 93 N.Y. 2d 729, 740 (1999) (PL §450.10 "provides a mechanism for returning allegedly stolen property to an owner prior to, or during the pendency of, a criminal proceeding"). ${ }^{83}$

WHEREFORE, it is respectfully requested that the Court grant this Application for an Order returning the Head of Alexander to representatives of the Italian Republic.

Matthew Bogdanos Chief of New York's Antiquities Trafficking Unit. New York County District Attorney's Office

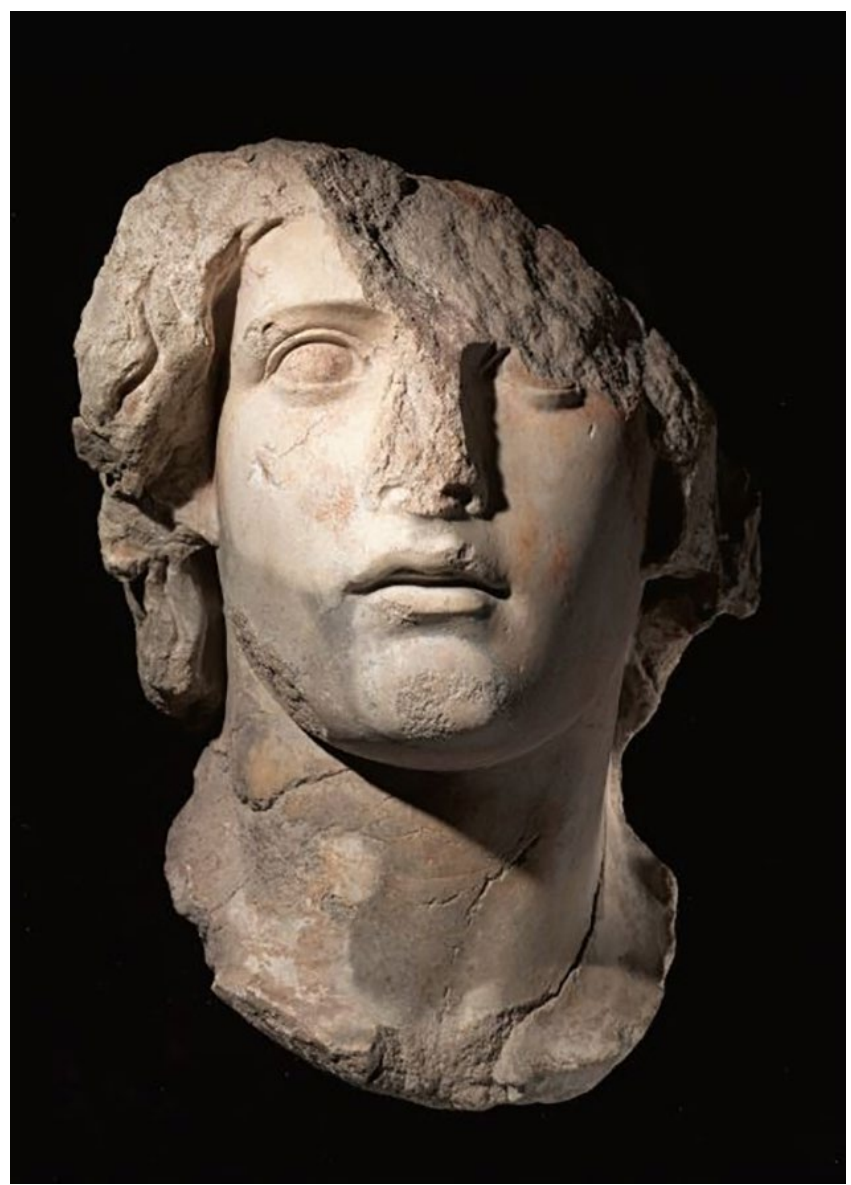

statute of limitations for any criminal prosecution for the alleged theft...ran out literally decades ago.” At $\$ 18$. Such a claim is obviously irrelevant unless this proceeding were being held in Italy. And even if we were in Italy, the stolen Head would not lose its status as stolen property merely because the Italian statute of limitations for the theft (ten years) or illegal export of an antiquity (six years) had run. The Head would still be stolen, but no one could be prosecuted.

82. This section in the original application, for reasons of length of the paper, is omitted from the present text (editors' note).

83. This Office is under a similar mandate: "[a]ll property delivered into the custody and held and kept by the district attorney of the county of New York, for use as evidence or otherwise, in any criminal investigation, action, appeal, or other proceeding, shall be returned by him to its rightful owner upon proper demand therefor.” N.Y. County Law §935. 
